\title{
The Behavior of TB-DM Patients in Controlling Blood Sugar Concentration in Medan City Community Health Center
}

\author{
Evawany Yunita Aritonang ${ }^{\mathrm{a},{ }^{*}}$, Sori Muda Sarumpaet ${ }^{\mathrm{b}}$, Syarifah ${ }^{\mathrm{c}}$ \\ ${ }^{a}$ Community Nutrition Department, University of Sumatera Utara, Medan, 20155, Indonesia \\ ${ }^{b}$ Epidemiology Department, University of Sumatera Utara, Medan, 20155, Indonesia \\ ${ }^{c}$ Health Education and Behavioral Sciences Department, University of Sumatera Utara, Medan, 20155, Indonesia \\ Corresponding author: *evawany@gmail.com
}

\begin{abstract}
North Sumatra is the region with the highest prevalence of pulmonary tuberculosis in Indonesia, 759 per 100,000 population aged $>15$ years. The male group had a higher prevalence of $T B$ than women $(1,083$ versus 461$)$. The incidence of pulmonary tuberculosis in Medan is still high (129 per 100,000 population). This showed that the burden of TB in Indonesia is still high. Patients with type 2 diabetes are more susceptible to pulmonary TB than non-DM, even though they get good nutrition and were established socioeconomically. This is because microorganisms grow well in high blood glucose concentrations when the body is weak and DM complications. Pulmonary infection worsens DM and increases blood sugar concentration (BSC). This study aims to analyze the behavior of TB-DM patients in all Community Health Centers in Kota Medan in controlling the BSC. The design of this study was a cross-sectional study with a population of all TB-DM patients who took medication at the Medan City Community Health Center. The sampling technique used accidental sampling for two months with a sample size of 68 respondents. Data collection was done by interviewing the TB-DM patients. The results showed that people aged $\geq 40$ years and most were men with low education. Respondents' knowledge about DM was low, respondents' knowledge about TB-DM was high, while respondents' attitudes and behavior were good. The chi-square analysis test showed no relationship between knowledge about DM and the behavior of TB-DM patients. There was no relationship between knowledge about TB-DM and the behavior of TB-DM patients, but there was a relationship between the attitudes and behavior of TB-DM patients.
\end{abstract}

Keywords - Knowledge; attitudes; behavior; patient with TB-DM.

Manuscript received 4 Dec. 2019; revised 15 Mar. 2021; accepted 27 Apr. 2021. Date of publication 31 Oct. 2021. IJASEIT is licensed under a Creative Commons Attribution-Share Alike 4.0 International License.

\section{INTRODUCTION}

Tuberculosis and Diabetes Mellitus are hitting Asian countries currently; therefore, it is called a double burden [1]. Diabetes Mellitus (DM) patients are more likely to develop pulmonary tuberculosis than non-DM patients [2]. Hyperglycemia in DM patients causes the impaired function of neutrophils and monocytes, affecting chemotactic function, phagocytosis, and decreased bacterial killing power. The decreased immunologic response in a person facilitates the development of infectious diseases, including mycobacterium tuberculosis. Defects cause the increased incidence of pulmonary tuberculosis in DM patients in immune cell function and defense mechanisms. In addition, it is also determined by the reduced leukocyte bactericidal activity in DM patients, especially for those whose blood glucose concentrations are not controlled.
Patients with diabetes type 2 are more susceptible to pulmonary TB compared to non-DMs, though they are wellnourished and established socio-economically. This is because microorganisms grow well if the blood glucose level is high. Therefore, the body's defense mechanism is weak. Patients with TB-DM can reduce the body's immunity and cause impaired innate and adaptive cellular responses. However, this cellular response has an especially important role as a barrier to the spread of TB infection. The incidence of TB-DM is $5.6 \%$ in India, $7.3 \%$ in Turkey, and in Indonesia, $14.8 \%$ of all DM patients. Tuberculosis has a relationship with DM. Research by Alisjahbana et al. in Susilawati and Muljati [3] showed a risk of TB 4.7 times in people with DM and 4.2 times in glucose intolerance compared to normal blood glucose levels. DM patients tend to feel hungry, so they need a snack that is low in carbohydrates and high in protein and vitamin B6, Vitamin D, and Zinc. 
Controlling blood sugar levels can prevent complications from other diseases. Therefore, the intervention to reduce sugar levels in diabetes is to increase knowledge, attitudes, and behaviors, such as low consumption, physical activity, and proper diet. Management for DM patients is to maintain blood glucose concentration to keep them under control by regulating the nutrition consumed. The DM diet arrangement includes three elements (type, amount, and meal schedule). Based on the above problems, the purpose of this study was to analyze the behavior of TB-DM patients in Medan City Community Health Center in controlling blood sugar concentrations. The objective of this study was to prevent DM patients from tuberculosis as well. By looking at the behavior of TB-DM patients in controlling their blood sugar concentration, it can provide knowledge so that the disease gets well.

\section{MATERIALS AND METHODS}

\section{A. Design, Time and Location Research}

This cross-sectional study was conducted to see the relationship between the attitudes and behavior of TB patients, the relationship between TB-DM knowledge and the behavior of TB-DM patients in Medan City, and the relationship between knowledge about DM and the behavior of TB-DM patients.

\section{B. Population and Sample}

Population and sample were all TB-DM patients who did the treatment at Community Health Centre in Medan City within two months of research. The sampling technique used accidental sampling for two months. The total samples are 89 respondents. Data collection was conducted by interview using a questionnaire at the community health center-data analysis using Chi-Square.

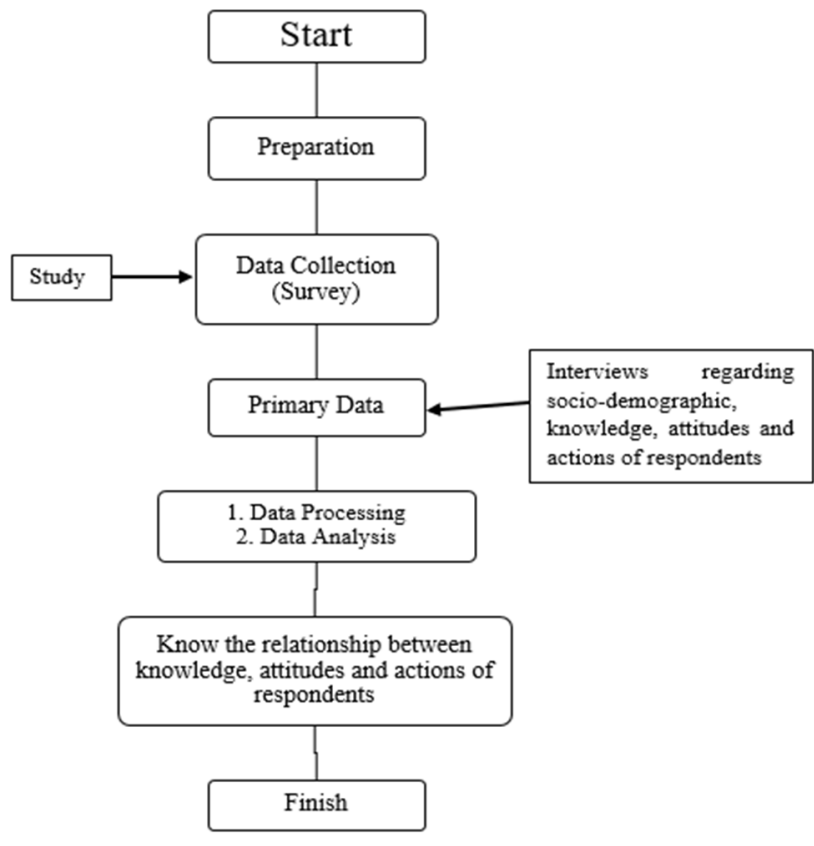

Fig. 1 Study Design Framework

According to Green [4], the factors that cause behavior are predisposing factors (knowledge, attitudes of trust and belief), enabling factors (facilities, infrastructure), reinforcing factors (family support and health workers). Therefore, to change DM patients' behavior to prevent them from becoming TB, we used Green theory [4] for the approach.

\section{RESULTS AND DISCUSSION}

\section{A. Characteristics of TB-DM Patients}

Based on Table I, the results showed that most of the age group of TB-DM patients are aged $\geq 40$ years $(97.1 \%$ ), similar to a previous study [5] that most TB patients were 49-61 years old. Commonly TB occurred in adults for two reasons. First, adults who have been infected with primary $\mathrm{TB}$ in their environment as a child but were not properly prevented so that it appears again in adulthood. The second possibility is the activity and work environment in adult groups who interact with TB patients or in an environment that makes it easy for them to become infected.

TABLE I

THE CHARACTERISTICS OF TB-DM PATIENTS

\begin{tabular}{cccc}
\hline No & $\begin{array}{c}\text { Characteristics of TB- } \\
\text { DM Patients }\end{array}$ & $\mathbf{N}$ & \% \\
\hline 1 & Age (year) & 2 & 2.9 \\
& $\bullet \quad<40$ & 66 & 97.1 \\
2 & $\bullet \quad \geq 40$ & & \\
& Gender & 44 & 64.7 \\
3 & $\bullet \quad$ Man & 24 & 35.3 \\
& $\bullet \quad$ Woman & 40 & 58.8 \\
& Education level & 28 & 41.2 \\
\hline & $\bullet \quad$ Low & 68 & 100 \\
\hline
\end{tabular}

The group that experienced the most TB in this study were men (64.7\%). This is also the same as Fauziah's research [5] in the Internal Medicine Inpatient Installation of Dr. M. Djamil Padang showed that most pulmonary TB patients with DM were men, as many as 17 people $(58.62 \%)$. The crude prevalence rate slightly higher in males compared to females [6]. Research by Hapsari and Muhammad [7] in Tambaksari Subdistrict Surabaya showed that TB patients with DM are most likely found in males, as many as 23 people $(60.5 \%)$. This is under WHO report [8] that more men suffered from TB globally. There are several reasons why men are more at risk than women, such as smoking habits in men. Smoking can increase the risk of contracting TB by two times [9].

In this study, the education of most respondents was low education (58.8\%). Harso study [10] stated that most TB patients with DM have formal education until graduating from Senior High School is 49 people (43\%). Education is a factor that influences a person in seeking treatment. A person's education will impact the occupation that is leading to access to get better healthcare also improve.

\section{B. Body Weight, Height, Blood Sugar Concentration at Time, House Size, Ventilation Area of TB-DM Patients}

Pulmonary TB is living in a densely populated house. A previous study showed that density is strongly associated with TB occurrence [11]. Selviana research [12] in the working area of Sungai Durian health center showed a $60 \%$ density level. From the table above, we found the house size was around 103.01 with 63.07 of Standard Deviation. It is shown 
that there was a variability of house size in this study. The Health Ministry of Indonesia recommends that many house sizes consider the number of residents of the house. If house size is not proportional will cause overcrowded. In addition, it also causes a lack of oxygen, and transmission of infectious diseases will be easier. The number of residents of the house was about four people. Hence, it still fulfills the standard of health house size.

TABLE II

Distribution OF TB-DM PATIENTS By BODY WEIGHT, HEIGHT, BLOOD Sugar LeVels AT Time, House Size, NumBer of REsidents, VENTILATION AREA

\begin{tabular}{|c|c|c|c|}
\hline Characteristic & $\mathbf{N}$ & $\begin{array}{r}\text { Mean (Min- } \\
\text { Max) }\end{array}$ & SD \\
\hline Body Weight & 68 & $\begin{array}{r}59.25(37- \\
90)\end{array}$ & 11.06 \\
\hline Body Height & 68 & $\begin{array}{r}163.84(145- \\
185)\end{array}$ & 7.84 \\
\hline $\begin{array}{l}\text { Current Blood Glucose } \\
\text { Concentration }\end{array}$ & 68 & $\begin{array}{r}233.85(66- \\
100)\end{array}$ & 105.39 \\
\hline House Size & 68 & $\begin{array}{r}103.01(16- \\
323)\end{array}$ & 63.07 \\
\hline $\begin{array}{l}\text { Number of residents of } \\
\text { the house }\end{array}$ & 68 & $4.40(1-11)$ & 1.97 \\
\hline Ventilation Size & 68 & $5.59(1-20)$ & 4.73 \\
\hline
\end{tabular}

Research by Ricardo et al. [13] in the work area of the Health Centers East Kelayan stated that there was a significant relationship between the condition of ventilation of the house with the incidence of pulmonary TB with a pvalue $=0.001$. Sulung and Nunung's research [14] also stated a significant relationship between nutritional status, ventilation, smoking habits, and the role of health workers with pulmonary TB events in the work area of the Health Centers.

\section{Knowledge, Attitudes, and Behaviors of TB-DM Patients}

Almost all patients can answer questions correctly about the nature of DM disease, which has a non-communicable disease and can occur due to heredity, causes, and symptoms of DM. $5.9 \%$ of patients answered this question incorrectly by answering that DM was a contagious disease. The knowledge that is still not understood correctly is that side dishes or processed foods can quickly increase blood sugar levels, behaviors took if blood sugar levels are normal, and the cause of DM patients is more easily infected with TB.

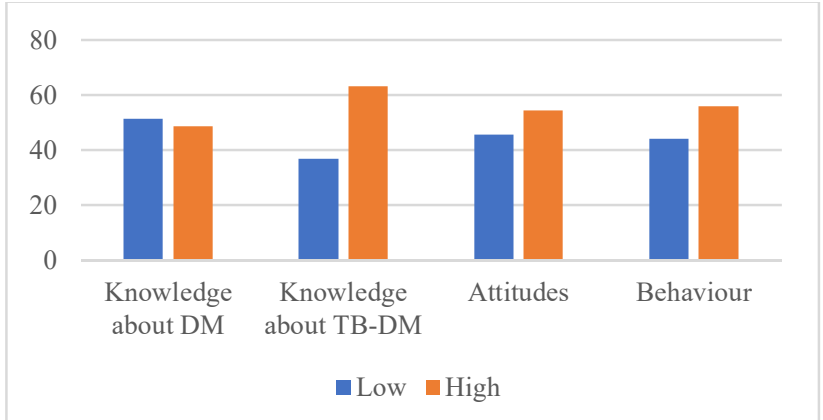

Fig. 2 Distribution OfTb-DM Patients Based On Knowledges, Attitudes, and Behavior

Nurmalini's research results [15] in patients at H. Adam Malik General Hospital also showed that $75.8 \%$ of patients correctly answered questions about the symptoms of DM.
Questions about the symptoms of DM were answered correctly almost by all patients because it was felt by patients when exposed to DM.

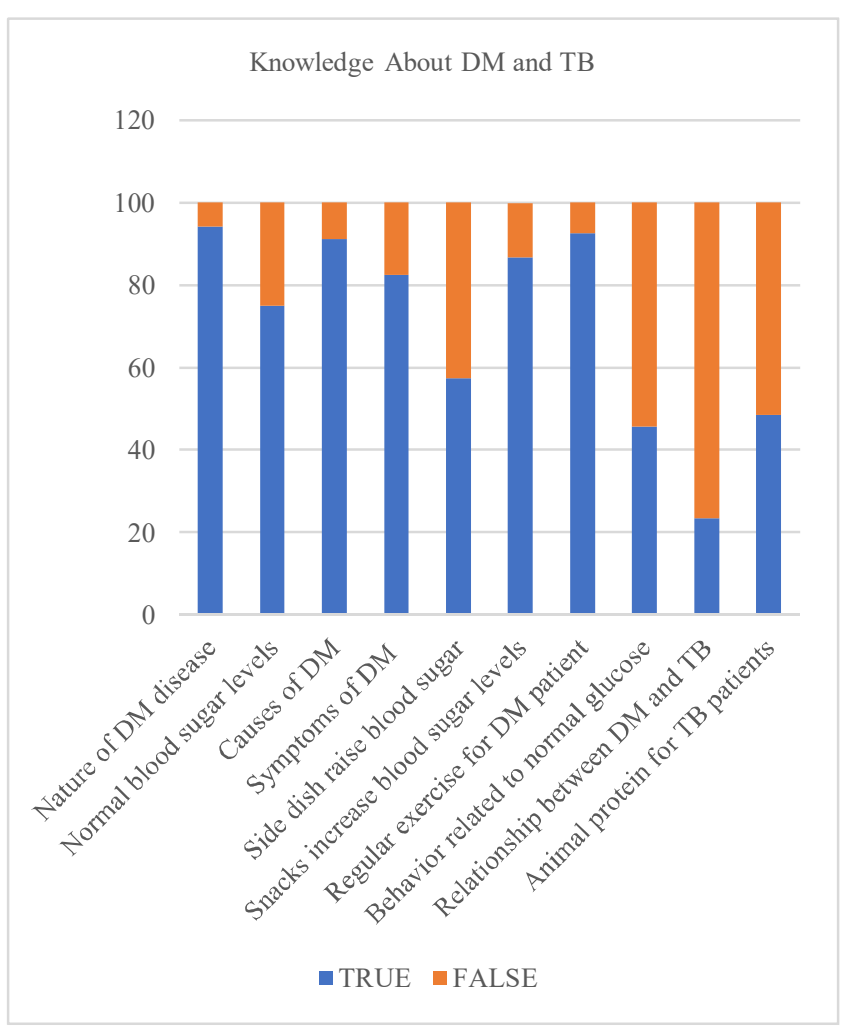

Fig. 3 Knowledge about DM and TB

Apart from eating patterns, physical activity exercise is also an influential thing in controlling blood sugar levels. Based on the study results, as many as $92.6 \%$ of patients were able to answer correctly about exercise functions for people with DM. Based on Ermawati's research [16] at Panembahan Senopati Hospital in Bantul, respondents' knowledge about sports questions in DM management was divided into 3 types of questions: intensity, time, and time and type of exercise. All respondents $(100 \%)$ can correctly answer questions about exercise intensity, 20\% correctly answer questions about exercise time, and $33.3 \%$ correctly answer sports-type questions in DM management.

The statement that DM TB patients were more difficult to recover than TB patients alone, as much as $94.1 \%$. This is in line with the knowledge score in the high category about the difference between DM or TB patients and DM TB patients as many as $88.2 \%$ of patients answered the questions correctly. Patients correctly answer that DM TB patients must take longer, more drugs, have more difficulty recovering, so it was more difficult to manage food consumption than TB patients alone. This showed that patients already have attitudes that are in line with the knowledge gained.

Based on Figure 3, most of the respondents answered wrong about the relationship between DM and TB. They did not know that DM patients tend to get TB easily. In general, we can summarize that respondent had good knowledge about DM and TB, except for the association between DM and TB. 


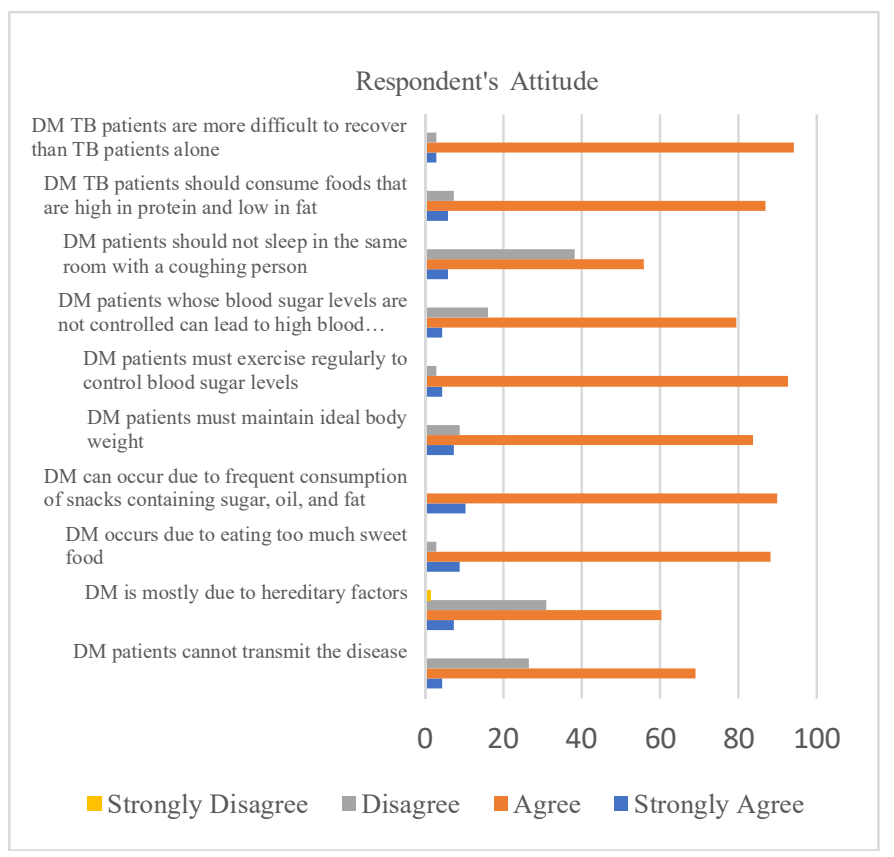

Fig. 4 Respondent's Attitude

The attitude of respondents was in line with their knowledge. Most of the respondents agreed that DM patients cannot transmit the disease. DM is related to hereditary factors and occurs due to eating too much sweet food. DM can occur due to frequent consumption of snacks containing sugar, oil, and fat. DM patients must maintain ideal body weight and must exercise regularly to control blood sugar levels. DM patients whose blood sugar levels are not controlled can lead to high blood pressure. DM patients should not sleep in the same room as a coughing person. DM TB patients should consume foods that are high in protein and low in fat. DM TB patients are more difficult to recover than TB patients alone.

There were $54.4 \%$ of respondents doing physical activity regularly. Compared to the knowledge and attitude about exercise regularly, we found that most respondents have better knowledge and attitudes than the practice. This was shown that positive behavior does not always follow positive knowledge or attitudes and vice versa. According to Green [4] three factors can influence behavior, namely: predisposing factors (knowledge, attitudes of trust and belief), enabling factors (facilities, infrastructure), reinforcing factors (family support and health workers).

Most of the respondents open windows every day (92.6\%). Based on the interview, the respondent opened the window from morning to evening and already knew that opening the window intended to allow air exchange in the house. Some respondents did not open the window because it was uncomfortable because of outside noise and influenced by the respondent's knowledge. Based on the results of Susanti's research [17], it was found that as many as $66.67 \%$ of respondents routinely open windows every day. The results of statistical analysis showing p-value $=0.064$. It can be concluded that there was no relationship between opening a window with pulmonary TB incidence. The results of this study differ from the incidence of pulmonary $\mathrm{TB}$ in the provinces of DKI Jakarta, Banten, and North Sulawesi, with $\mathrm{p}$-value $=0.046$ and $\mathrm{OR}=1.731$ with $95 \% \mathrm{CI}=1,008-1,836$.
The difference in results can be due to knowledge about pulmonary TB prevention behavior [17].

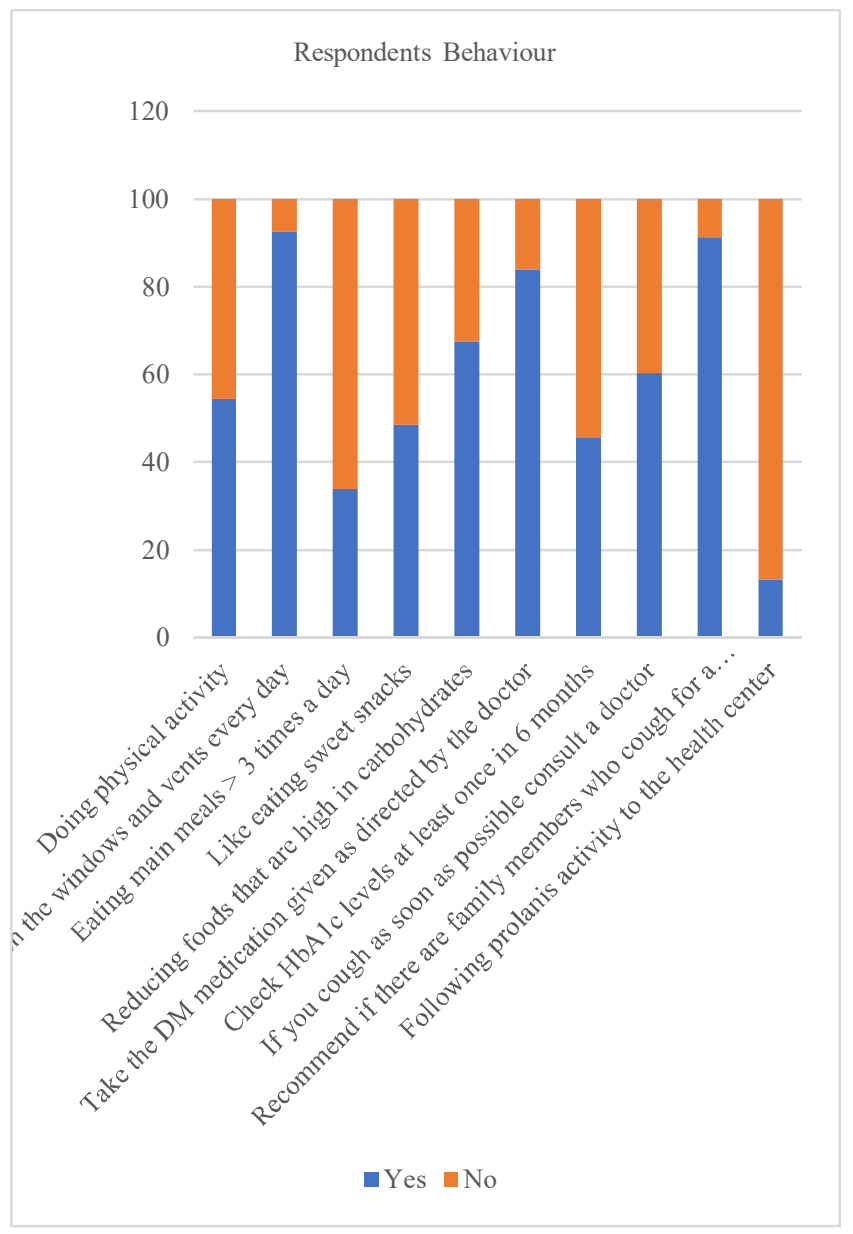

Fig. 5 Respondent's Behavior

Okatiranti and Nuraeni's research [18] in the Polyclinic in Bandung City Hospital showed that most DM patients had less knowledge as many as 26 people $(44.06 \%)$. This is different from the research of Patimah et al. [19], showing that of the 30 respondents studied, most DM patients had good knowledge totaling 16 respondents $(53.3 \%)$. Budi [20]showed that in Palembang City, out of 192 people slum community, there were $60.42 \%$ who did not have good knowledge about the causes of tuberculosis, transmission and prevention of disease $39.58 \%$ were good and supportive. By this study, we found that TB-DM patients still have a habit of eating sweet food. Dietary patterns are one of the leading factors of Diabetes Mellitus [21]. We also found that only $13.2 \%$ of respondents went to health center for prolines activity. A previous study shown that there was a relationship between prolines activity with the prevention of chronic diseases [22].

\section{Relationship of Knowledge about DM with Behaviors of TB-DM Patients in Medan City}

Based on table III, it shown that 35 respondents who have low knowledge have bad behaviors by $54.3 \%$, while respondents with high knowledge level of bad behaviors amounted to $33.3 \%$. From the results of the statistical test analysis $p$ value $>0.05$ which means there is no relationship 
between knowledge about DM with the behaviors of TB-DM patients in Medan City.

TABLE III

RELATIONSHIP OF KNOWLEDGE ABOUT DM WITH BEHAVIORS OF TB-DM PATIENTS IN MEDAN CiTY

\begin{tabular}{|c|c|c|c|c|c|c|c|c|}
\hline \multirow{3}{*}{ Knowledge } & \multicolumn{6}{|c|}{ Behavior } & \multirow{3}{*}{$\begin{array}{c}\text { PR } \\
(95 \% \\
\text { CI })\end{array}$} & \multirow{3}{*}{$p$} \\
\hline & \multicolumn{2}{|c|}{ Not good } & \multicolumn{2}{|c|}{ Good } & \multicolumn{2}{|c|}{ Total } & & \\
\hline & $\mathbf{n}$ & $\%$ & $\mathbf{n}$ & $\%$ & $\mathbf{N}$ & $\%$ & & \\
\hline \multirow[t]{2}{*}{ Low } & 1 & 54. & 1 & 45. & 3 & 10 & \multirow{2}{*}{$\begin{array}{c}2.375 \\
(0,889\end{array}$} & \multirow[b]{2}{*}{0.13} \\
\hline & 9 & 3 & 6 & 7 & 5 & 0 & & \\
\hline \multirow[t]{2}{*}{ High } & 1 & 33. & 2 & 66. & 3 & 10 & - & \multirow[t]{2}{*}{5} \\
\hline & 1 & 3 & 2 & 7 & 3 & 0 & $6,347)$ & \\
\hline
\end{tabular}

According to the previous study, this result stated that subjects who had higher knowledge about DM tend to have good behavior [23]. This was not the same with Perdana research [24] stated that there was a relationship between the knowledge about DM of DM patients with blood glucose control. The better level of knowledge about DM of DM patients, the more controlled their blood glucose concentration. Based on the research results during the interview process in the field with respondents, the average respondent had long suffered from DM. Respondents have knowledge about DM disease from healthy centers staff who conduct counseling at health centers and family or friends. Even though the respondents knew about DM disease, some did not carry out their behaviors. For example, respondents know that DM patients should control the consumption of sweet foods, but respondents still consume these sweet foods. Some also know that people with diabetes should take antidiabetic medication regularly, but they do not take medicine even though it has been recommended by a doctor or health staff [24].

\section{E. Relationship of Knowledge about TB-DM with Attitudes of TB-DM Patients in Medan City}

Table IV shows that out of 25 respondents who know low TB-DM have adverse behaviors of $56 \%$. In comparison, respondents who have high knowledge of unfavorable behaviors were $37.2 \%$.

TABLE IV

RELATIONSHIP OF KNOWLEDGE ABOUT TB-DM WITH ATTITUDES OF TB-DM PATIENTS

\begin{tabular}{|c|c|c|c|c|c|c|c|c|}
\hline \multirow{3}{*}{ Knowledge } & \multicolumn{6}{|c|}{ Attitudes } & \multirow{3}{*}{$\begin{array}{c}\text { PR } \\
(95 \% \\
\text { CI })\end{array}$} & \multirow{3}{*}{$\boldsymbol{P}$} \\
\hline & \multicolumn{2}{|c|}{ Not good } & \multicolumn{2}{|c|}{ Good } & \multicolumn{2}{|c|}{ Total } & & \\
\hline & $\mathbf{n}$ & $\%$ & n & $\%$ & $\mathbf{N}$ & $\%$ & & \\
\hline Low & 14 & 56 & 11 & 44 & 25 & 100 & $\begin{array}{c}2.148 \\
(0.788-\end{array}$ & 0.211 \\
\hline High & 16 & 37.2 & 27 & 62.8 & 43 & 100 & $5.856)$ & \\
\hline
\end{tabular}

The statistical test analysis $p$ value $>0.05$ means there is no relationship between knowledge about TB-DM with the behaviors of TB-DM patients in Medan City. This is the same as Kurniawati's [25] research on the knowledge and behavior of tuberculosis patients about their disease and its treatment that with high knowledge about their illness respondents have behaved positively toward behavior in preventing disease transmission. The higher or better a person's level of knowledge or understanding of an object, the better the person's attitude to that object. Based on the results of research on TB-DM respondents, some have high knowledge.

\section{F. Relationship between Attitudes about TB-DM with Behaviors of TB-DM Patients}

Based on table $\mathrm{V}$ it can be seen that 31 respondents who had bad attitudes with bad behaviors amounted to $67.7 \%$. In comparison, respondents who had good attitudes with unfavorable behaviors were only $24.3 \%$. From the statistical test analysis results, the value of $p<0.05$ means that there is an influence between attitude and behaviors of TB-DM patients in Medan.

TABLE V

RELATIONSHIP BETWEEN ATTITUDES ABOUT TB-DM WITH BEHAVIORS OF TB-DM PATIENTS

\begin{tabular}{|c|c|c|c|c|c|c|c|c|}
\hline \multirow{3}{*}{ Attitude } & \multicolumn{6}{|c|}{ Behavior } & \multirow{3}{*}{$\begin{array}{c}\text { PR } \\
(95 \% \\
\text { CI) }\end{array}$} & \multirow{3}{*}{$P$} \\
\hline & \multicolumn{2}{|c|}{ Not Good } & \multicolumn{2}{|c|}{ Good } & \multicolumn{2}{|c|}{ Total } & & \\
\hline & n & $\%$ & n & $\%$ & $\mathbf{N}$ & $\%$ & & \\
\hline Not & 21 & 67.7 & 10 & 32.3 & 31 & 100 & 6.533 & 0.001 \\
\hline Good & & & & & & & (2.256- & \\
\hline Good & 9 & 24.3 & 28 & 75.7 & 37 & 100 & 18.924) & \\
\hline
\end{tabular}

This was the same as Rizana's [26] research on knowledge, attitudes, and behaviors in preventing pulmonary tuberculosis transmission that there is an influence of health education on attitudes and behaviors in preventing $\mathrm{TB}$ transmission. Likewise, in Suradnyana's research [27], there is a link between individual attitudes and behaviors. The individual's attitude was based on knowledge which will then carry out or practice something that is known (judged good). Based on Ariani [28] regarding the regularity of taking medicine for patients with pulmonary tuberculosis in the working area of Modayag Health Centre, Bolaang Mongondow Regency that there was a significant relationship between attitude and regularity of taking medication, with OR value of 8,800 .

\section{CONCLUSION}

The results showed a relationship between the attitudes and behavior of TB-DM patients $(\mathrm{p}=0.001)$. There was no relationship between TB-DM knowledge and the attitudes of TB-DM patients in Medan City $(p=0.211)$. There was no relationship between knowledge about DM with TB-DM patient behavior in Medan City. $(p=0.135)$. Thus, TB control programs should focus on knowledge improvement and changing attitudes and behavior. Based on Green Theory [4], behavior is determined by three factors. This study shows that knowledge, attitudes, and behavior did not always work in accordance. Green Theory [4] proves that besides predisposing factors (knowledges and attitudes), enabling factors and reinforcing factors also need to form a TB-DM patient behavior. In the future, this study should be broadened with enabling factors and reinforcing factors to see how predisposing, enabling, and reinforcing factors made a positive behavior to prevent TB-DM patients. A study about how strong relationship between attitudes and behavior of TB-DM patients should be conducted in the future. 


\section{ACKNOWLEDGMENT}

The researchers are grateful to Kemenristik-Dikti that funded this research through DRPM Kemenristekdikti funds in 2019. Researchers also are obliged to all the respondents (TB-DM patients) willing to be sampled in this study.

\section{REFERENCES}

[1] C. Zheng, M. Hu, and F. Gao, "Diabetes and pulmonary tuberculosis: a global overview with special focus on the situation in Asian countries with high TB-DM burden," Glob. Health Action, vol. 10, no. 1, 2017, doi: 10.1080/16549716.2016.1264702.

[2] B. I. Restrepo, "Diabetes and tuberculosis," Underst. Host Immune Response Against Mycobacterium Tuberc. Infect., vol. 4, no. 6, pp. 121, 2018, doi: 10.1007/978-3-319-97367-8_1.

[3] M. D. Susilawati and N. Muljati, "Hubungan Antara Intoleransi Glukosa dan Diabetes Melitus dengan Riwayat Tuberkulosis Paru Dewasa di Indonesia (Analisis Lanjut Riskesdas 2013)," Media Penelit. dan Pengemb. Kesehat., vol. 26, no. 2, pp. 71-76, 2016, doi: 10.22435/mpk.v26i2.5443.71-76.

[4] L. W. Green, J. M. Ottoson, C. García, R. A. Hiatt, and M. L. Roditis, "Diffusion theory and knowledge dissemination, utilization and integration.," Front. public Heal. Serv. Syst. Res., vol. 3, no. 1, p. 3, 2014, [Online]. Available: http://www.ncbi.nlm.nih.gov/pubmed/26251771.

[5] A. M. Fauziah, DF., Masrul B, "Incidence of Pulmonary Tuberculosis in Diabetes Mellitus Tip 2 Patients in Internal Medicine Inpatients Dr. M. Djamil Padang," J. Kesehat. Andala, vol. Vol.5 No.2, 2016.

[6] G. Segafredo et al., "Integrating TB and non-communicable diseases services: Pilot experience of screening for diabetes and hypertension in patients with Tuberculosis in Luanda, Angola," PLoS One, vol. 14, no. 7, 2019, doi: 10.1371/journal.pone.0218052.

[7] P. N. Fitri and M. A. Isfandiari, "The Association of Socioeconomic and Nutritional with Risk of Tuberculosis in DM Type 2 Patient," $J$. Berk. Epidemiol., vol. 5, no. 2, 2017, doi: 10.20473/jbe.v5i22017.185194.

[8] World Health Organization (2018). Tuberculosis in women, from https://www.who.int/tb/publications/tb_women_factsheet.pdf

[9] F. Panjaitan, "Characteristics of Adult Pulmonary Tuberculosis Patients in the General Hospital Dr. Soedarso Pontianak Period September - November 2010.," 2013.

[10] A. Y. \& M. K. Harso, AD., Armaji KS, Dona A, Retna MI, Aris Y, "Differences of Sociodemography Factors and Nutrition Status of Tuberculosis Patients with and Without Diabetes Based on Tuberculosis-Diabetes Mellitus Registry 2014," J. Media Litbang, vol. Vol. 27 No, 2017.

[11] S. K. Singh, G. C. Kashyap, and P. Puri, "Potential effect of household environment on prevalence of tuberculosis in India: Evidence from the recent round of a cross-sectional survey," BMC Pulm. Med., vol. 18, no. 1, 2018, doi: 10.1186/s12890-018-0627-3.

[12] I. Selviana., Hernawan, Andri., Khitama, "Spatial Analysis of Case and Environmental Distribution Potential for Lung Tuberculosis Transmission,” J. Vokasi Kesehatan., vol. Vol 2 No., 2016.
[13] H. Ricardo, F., Heriyani, F., \& Khatimah, "Incidence Lung TB in the Kelayan Timur Health Center Area," Period. Bull. Med., vol. Vol. 12 No, 2016.

[14] N. \& N. G. Sulung, "Relationship Between Nutritional Status, Ventilation, Smoking Habits And The Role Of Health Workers With Pulmonary Tuberculosis," J. Pembang. Negeri, vol. Vol. 3 No., 2017.

[15] F. Nurmalini, "Knowledge Description of Type 2 DM Patients Against Disease and Management of Type 2 DM in H. Adam Malik General Hospital Medan July - August 2010. (Student Paper)," Medan, 2010.

[16] Z. Ermawati, "Description of Knowledge and Attitudes About Disease Management in Patients with Diabetes Mellitus in Panembahan Senopati District General Hospital Bantul," Yogyakarta, 2011.

[17] I. Susanti, L, "Relationship Between Physical Conditions of the House and Behavior with the Occurrence of Pulmonary Tuberculosis in the Work Area of the Sangkrah Community Health Center, Surakarta City,' Surakarta, 2016

[18] O. \& N. H, "Overview of Knowledge, Attitudes and Beliefs Against Diet of DM Patients in RSUD Kota Bandung," J. Nurs., vol. Vol. 4 No., 2016.

[19] V. E. Patimah, Wasisto U, "Relationship of Knowledge About Diabetes Mellitus Complications with Behavior in Preventing Disease Complications in Patients with Diabetes Mellitus," J. Nurs. Univ. Riau, 2018.

[20] D. Budi, I. S., Ardilah, Y., Sari, I. P., \& Septiawati, "Risk Factor Analysis of Tuberculosis Occurrence for Slum Communities in Palembang City," J. Kesehat. Lingkung. Indones., vol. 17(2), pp. 8794, 2018, doi: 10.14710/jkli.17.2.87-94.

[21] Khazrai YM, Defeudis G, Pozzilli P. Effect of diet on type 2 diabetes mellitus: a review. Diabetes Metab Res Rev. 2014 Mar;30 Suppl 1:24 33. doi: $10.1002 / \mathrm{dmrr}$ 2515. PMID: 24352832.

[22] A. Susiani and R. Magfiroh, "Pengaruh Pelaksanaan Kegiatan Prolanis Terhadap Kekambuhan Hipertensi," J. Kesehat., vol. 11, no. 1, pp. 1386-1395, Jun. 2020, doi: 10.38165/jk.v11i1.191.

[23] A. M. J. December, "Level of Knowledge about Tuberculosis among Type 2 Diabetes Mellitus Patients at the Endocrine Clinic Dr. Hasan Sadikin General Hospital Bandung," vol. 4, no. December, pp. 512$517,2017$.

[24] U. Perdana, A. A., Ichsa, B,. Rosyidah, D, “The Relationship Between Knowledge Levels of DM Disease and Control of Blood Glucose Levels in Type II DM Patients in PKU Muhammadiyah Hospital Surakarta," 2013.

[25] Karuniawati, Hidayah, Arifah Sri Wahyuni, and Heni Mirawati. "Pengetahuan dan perilaku pasien tuberkulosis terhadap penyakit dan pengobatannya." In Prosiding Seminar Nasional \& Internasional. 2015.

[26] M. Rizana, N., Tahlil, T, "Knowledge, Attitudes and Family Behavior in Prevention of Lung Tuberculosis Transmission," 2016.

[27] A. Suradnyana, I, G, M,. Rahem, A, "The Effect of Patient Decision Aid on the Level of Knowledge, Attitudes, Behaviors and Clinical Results of Treatment of Type 2 Diabetes Mellitus Patients," 2018.

[28] B. Ariani, N, W.. Rattu, A, J., Ratag, "Factors Associated with Regularity of Taking Drugs for Patients with Pulmonary Tuberculosis in the Modayag Community Health Center Area, East Bolaang Mongondow Regency," 2015. 